\title{
Climate Change and Environmental Consequences in Nepal
}

\author{
- Mr.shambhu paudel*
}

From the wind-swept peak of the world's highest mountains to the lowland terai, Nepal boasts of an enormous wealth of natural and cultural diversity. Nepal's rich biodiversity is a reflection of its unique geography and varying latitude and climate, enclosed within $\mathrm{a}$ narrow stretch of land, only $150 \mathrm{~km}$ from south to north. Despite the size, Nepal is the $25^{\text {th }}$ richest country in the world in terms of biodiversity.

Entire human community of the globe has a feeling of warm and warm summer day in a row than that of the previous years. In contrast, they are experiencing no more cool and cool winters than the past ones. In macro level, the frequency of natural calamities mainly flood, wild fire, sporadic rainfall, reduction in agro forest production, epidemics and the earthquakes that are the consequences of global warming is accelerating dramatically every year. Global warming or climate change has become a crucial and targeted issue of the environment protection movements throughout the world. Such movements figure out that the produced Greenhouse gases (GHG) are the major causal entities of the global warming phenomenon.

Carbon dioxide, Methane, Nitrous oxide, Hydro fluorocarbons, per fluorocarbons and sulfur hexa-fluorides are categorized under the title of the major GHG. It is observed that the first three gases among aforementioned are the most prominent factors of the global warming indications in Nepalese context. Fuel wood burning and fossils fuel combustions account the main source of carbon dioxide production in the local atmosphere. Besides, ruminant animals and paddy production significantly increases the methane emission rate in this region. It is now understood that other gases have very nominal contribution for the global warming scenario.

In 1988, along with other top media houses, Time magazine triggered a deluge of public interests in global warming and climate change through its issue 'Planet of the Year: Endangered Earth'. This was the first time the world had given so much importance to climate change although scientists had given hints about it as early as 1896! The magazine had inter alia spelt out warnings of ozone layer depletion, bio-diversity losses and ice meltdown. Time had clearly listed its 19-point action agenda as well although they were hardly executed.

Nineteen years later, the last week's issue of Time again made the world stand and stare through its cover story "who owns the arctic". Based on the recent scientific findings, the magazine has reported that the blanket of ice in Arctic is fast depleting, opening up massive stretches of water bodies. It seems that the global warming is finally taking a toll on polar ice cap, one of earth's last untouched landscapes. US Geological Survey has predicted a 40 percent decline in ice cover by 2050 along with the disappearance of twothirds of species like polar bear, red necked seal and cod.

In global scale, Nepalese GMG emission seems negligible. Carbodioxide is the main contributor for global warming. Other GHG such as methane and nitrous oxides are equally important because they have more warming potentiality then carbon dioxide. In comparison to methane and nitrous oxide gases, carbon dioxide possesses lesser capacity to absorb the solar radiation. A study proved that methane can trap 21 times more solar radiation than carbon dioxide and nitrous oxides trap 310 times more than carbon dioxides. Nepalese energy consumption pattern is entirely opposite to that of global context. The largest fraction $(83.53 \%)$ of energy depends upon the traditional and convectional energy sources-mainly fuel wood $(75.78 \%)$, agriculture residue $(3.75 \%)$ and animal dung $(4 \%)$. Commercial sources score the second largest fraction $(16.47 \%)$ of the energy that is the sum of petroleum products $(9.24 \%)$, coal $(3.54 \%)$, electricity $(1.47 \%)$ and the others $(2.22 \%)$. The figure

${ }^{*}$ Kathmandu Forestry College, Kathmandu. 
indicates that major energy requirement is fulfilled from the forest sectors and as the consequences; deforestation practice is augmented haphazardly throughout the nation. As a result, store house of carbon is being distorted and GHG emission is increasing at increasing rate.

Recent study reported that pollution elicited by more than 200 Nepalese is equal to pollution elicited by one American. It was found that only $0.025 \% \mathrm{GHG}$ emission falls under the regime of Nepal. The amount GHG emission by Nepal is low in comparison to others but the effect of climate change, in which annual minimum temperature is being increased by $0.006^{\circ} \mathrm{C}$, is seen in Nepal too.

Based on 2003 report, carbon dioxide emission by different countries given below:

$\mathrm{CO}_{2}$ emission=per head $/$ metric ton

\begin{tabular}{|ll|ll|ll|}
\hline Country & $\mathbf{C O}_{2}$ & Country & $\mathbf{C O}_{\mathbf{2}}$ & Country & $\mathbf{C O}_{\mathbf{2}}$ \\
\hline USA & 121.32 & Russia & 10.3 & Italy & 7.7 \\
Quatar & 63.1 & Denmark & 10.1 & Spain & 7.3 \\
UAE & 33.6 & Norway & 9.9 & Belarus & 6.4 \\
Kuwait & 31.1 & Germany & 9.8 & Malaysia & 6.4 \\
Nether land & 22.7 & Japan & 9.7 & France & 6.2 \\
Australia & 18.0 & Newsland & 8.8 & Sweden & 5.9 \\
Canada & 17.9 & Cyprus & 8.9 & Iran & 5.6 \\
KSA & 13.0 & Austria & 8.6 & India & 1.19 \\
Finland & 13.0 & Belgium & 8.3 & China & 3.2 \\
Oman & 12.9 & Poland & 7.9 & Brazil & 1.6 \\
Singapore & 11.3 & South Africa & 7.8 & Nepal & 0.11 \\
\hline
\end{tabular}

\section{Kyoto protocol for climate change}

Kyoto protocol, which is the result of Global warming, initiated in December 1997. In the Kyoto city of Japan, 180 countries committed, common and enforce agreement, called Kyoto protocol. The prime aim of this protocol is to preserve the world from Global warming, to reduce the GHG emission and the air pollution.

According to UNEP "The effectiveness of Kyoto really depends of whether it lays a good foundation for the climate convention process, which might lead to greater reduction later." According to this protocol, 38 industrial states, within period of 2008 to 2012, must reduce their GHG emission by $5.2 \%$ than 1990 . Kyoto protocol came into play from the Feb.16, 2005 all over the world. It was opened from March, 16, 1998 for a year to sign. For the implementation of Kyoto protocol, it required formal ratification from at least 55 countries which must represent at least $55 \%$ GHG emission by developed countries.

Kyoto protocol is just the modification of "United Nation Framework Convention on Climate Change: Earth Summit". United States was against this protocol and Australia as supporter for United States at its early stage but these countries are under pressure to sign. Russia signed for this protocol on November 18, 2004. What is the use of this protocol when countries like USA, the biggest contributor to GHG are not a signatory? Kyoto protocol defined clearly the reduction of GHG emission for Europian Union by $8 \%$, USA by $7 \%$, Japan by $6 \%$, Australia by $8 \%$, Iceland by $10 \%$ and Russia by $0 \%$.

\section{Climate Change Impacts in Nepalese Land}

In 1994, the emission of GHG was estimated about $95,00,000$ tones of carbon dioxide per year. The largest fraction of the Carbon dioxide emission was obtained from the burnings of fuel woods throughout the country and was equivalent to over $81,00,000$ metric tones. The rest was from fossil fuel, agriculture and industrial process. In, 1997, traditional cropping system especially paddy crop produced $5,50,000$ metric tones of methane and livestock produced 3,70,000 metric tones of it in the country. Improper usage of Nitrogenous fertilizers 
in the agro forest land, the emission of nitrogen oxide into the atmosphere created difficulties to find out the right database. Climate change impacts in Nepalese land under the titles of biological, physical and social indications and consequences aspects will be more pragmatic.

\section{a. Biological indication and consequences}

Studies show that most of the high land plants are blossoming one week earlier due to the effects of global warming then their usual time period in Upper Mustang which was observed in 1996-98. Similar experience was also observed in polar plants namely Saxifrage spps. of polar region of Norway in past. Global warming changes the biome region which causes change in the Timber Line. Endemic spps are being extinct at fast rate. Physiology and phenology of plant spps are being changed; as a result genetic drift being seen in plant spps. Indicator species can be used to identify such changes in the plant community.

Not only does the global warming have strong influence to plants but also the effect is pronounced in zoological realms. Habitat range of some of the small insects mostly mosquitoes is shifting to higher elevation deviating from the normal habitat range of 1000$1500 \mathrm{~m}$. During summer days, people of Jomsom, located at $2700 \mathrm{~m}$, a district head quarters of Mustang, worry about mosquitoes and frequently use mosquito's net and repelling chemicals.

Spreading of tropical diseases due to the insect proliferation is also observed in recent years caused due to global warming. During the monsoon of 2000, more than 1000 people in the Terai region of Nepal get infected and around 300 of them die from Japanese Encephalitis, a mosquito-borne disease. There could still be a lot of such epidemics that are unnoticed to the concerned organizations and common people. Recent study has found out that pattern of infection is also changed due to Global warming.

Climate change practically impedes the production sector too. In last couple of year rural farmers of the country has observed reduction of winter cash crops production in western Terai of Nepal, one of the severe examples is found in fiscal year 1997/98. A survey shows that potato, mustard and cow-pea crops production were reduced by $28 \%, 38 \%$ and $31 \%$ respectively in '97-98' due to the strong winter overcast observed in the winter season in western Terai belt of Nepal resulting food and vegetables deficiency in local markets.

\section{b. Physical indications and consequences}

A study by environmental agencies early this year has revealed that the Nepal Himalaya has warmed by $1^{\circ} \mathrm{C}$ since 1970 s. UN has predicted that the present 500,000 sq. $\mathrm{km}$ of glacier could be reduced to just $100,000 \mathrm{sq} . \mathrm{km}$ within 2030 . UNEP experts in June 2007 gave out yet another warning that within the next 50 years, global warming could melt all Himalayan Glaciers leading to huge glacial lake outburst floods. Foremost is the Imja Glaciers south of Mt.Everest that is retreating by 70 meters every year. Similarly lower Barun Lake at $4,750 \mathrm{~m}$ is also on the verge of overflowing and affecting human settlements within a distance of 40 kilometers. The flood from Dikcho Lake that destroyed the Namche Hydro electric Project and killed five people in 1985 and Amadablam Glacier landslide that left six people dead in 1986 are likely to recur anytime in the Himalayas.

The uncontrolled increase in the number of trekkers and mountaineers in Everest region is sure to bring some drastic changes in the environment. Earlier this year the petition by Green peace to put Everest on' In Danger' List was also backed by Sir Edmund Hillary. Hillary who has also led Transatlantic and mechanized expedition to the South Pole has been outright and forthcoming against exploitations of Everest. He has time and again called on Nepali and Chinese governments to reduce stress on Everest by relaxing mountaineering activities for sometime. Looks like this will continue to fall on deaf ear for sometime.

A study report of Integrated Center for Integrated Mountain Development (ICIMOD), Kathmandu based independent research center and UNEP in the Asia Pacific region had 
recently published research report about present status of glaciers and glacial lakes in the Nepalese Himalayas. The report states that 3,252 glaciers site and 2,315 glacial lakes are found in Eastern Himalayan region of Nepal. The number and size of glacial lakes are dramatically increasing in last fifty years indicating that the global warming has caused an adverse impact in the region.

In 2000, the South Asian countries seriously suffer monsoon rainfall. It was reported that the incessant rainfall killed thousand of people and property worth billions lost in Bangladesh, Nepal and India. In 2001, monsoon rainfall diminished in the eastern part of Nepal, especially in Jhapa, Ilam, Morang, Sunsari, Dhankuta and saptari districts measured $570 \mathrm{~mm}$ in 2000 and $206 \mathrm{~mm}$ rainfall in the year. Partial rainfall was observed throughout the country in the days of 2001. In contrast heavy monsoon received in western hill region of Nepal mainly in Myagdi, Gulmi, Dhading, Dolakha, Sindupalchowk districts in July 2001.

Forest fire in the Mahabharat range forests was one of the largest forest fire in Nepalese history of wild fire that ablazed in 2000. The hottest year of the century is 1999. The heat dried up the forest bio-mass and reduced the soil water contains, as a result single spark of light could turn into greater fire in the forests. Temperature elevation was observed in last two decades in Nepal. The data showed that $0.06 \mathrm{C}, 0.12 \mathrm{C}$ and $0.03 \mathrm{C}$ had been increased in Himalayan, Mid-Hills and Churia region of the country respectively every year.

\section{c. Socio-economic impacts and consequences}

Cycle is disturbed due to global warming thus the agrarian society of Nepal is greatly suffering from heavy loss of crop production and consequently results an imbalanced annual house hold budget mostly in poor communities who have less crop field. Global warming created new habitats of mosquitoes in temperate and mountain region of the country. Poor people have to buy mosquito's net as well as repelling chemical for protection from mosquito's problem. It might put little pressure to the household economy of poor family. People from hill region also have been suffering from disturbance of hydrological cycle, its consequences is flood, landslide or natural hazard. The natural hazard has put major stress in poor community of the society because they could not build good houses and normally they do not have good land for agriculture. Normally we observe that the poor community settlements are generally found close to river bank and marginalized land. Unfortunately, they are greatly suffered from landslides and flood.

\section{The way Forward}

Nepal, being at a transitional phase, must make efforts to conserve its pristine biological resources for the benefit of the people that underpin a framework of stewardship to protect the environment while meeting social and economic needs and aspirations of the Nepali society. We need both biological diversity and cultural diversity, and we need diversity in our approaches to conservation. Our capacity to adapt to change will be based on the decisions we make today. Kyoto protocol, the need of today, only demands the excellent co-ordination and strong commitment of Nepal for its successful implementation. Carbon trading is an opportunity for Nepal, which requires Designator National Authority (DNA) under Ministry of Science and Technology. To get momentums of Global warming, campaigning in the country concerned organization have to develop right policy and effective program for specific sector in the field of international movement for Global Warming impact mitigation. There are three possibilities that are recommended for reduction of global warming impact significantly in Nepal. Firstly, awareness raising program must be conducted on global warming, its potential impact, consequences and mitigation measures to the local community. Secondly, effective management should be implemented to improve the existing forest management system for maintaining greenery in the country, and the last point to consider is to reduce the uses of greenhouse gases and to emphasize on promotion of clean energy technology. 